\title{
Don't Speak, Maharani: Raising Awareness Towards How Victim Blaming is Worsening Rape Survivor's PTSD
}

\author{
Arliga Kanza Al-Ayubi \\ English Department, Faculty of Languages and Literature, Petra Christian University, Siwalankerto 121- \\ 131, Surabaya 60236, INDONESIA \\ E-mail: arliga_kanza@gmail.com
}

\begin{abstract}
The screenplay Don't Speak, Maharani is the story of Maharani as a rape survivor who suffers from post traumatic stress disorder. Using drama as the genre of the story, the screenplay shows multiple struggles of Maharani who lives her life with unsupportive family which is worsening her psychological state. Since the screenplay focuses on the act of victim blaming which is worsening rape survivor's Post Traumatic Stress Disorder (PTSD), the story focuses on Maharani reaction towards the action given to her. As the plot advances, it shows how Maharani's PTSD is worsened by victim blaming given to her. In the end, Maharani tries to heal by taking drugs but she gets overdose. In order to create this screenplay, I use two concepts which are rape and PTSD and rape and victim blaming. The issues regarding victim blaming and PTSD are rarely brought up in a form of a screenplay. However, I believe victim blaming is an act of killing and needs to be stoped.
\end{abstract}

Keyword: Rape, Post Traumatic Stress Disorder, Victim Blaming.

\section{INTRODUCTION}

Rape is a concerning issue in Indonesia. Based on Lembar Fakta Catatan Tahunan in 2017 (CATAHU) National Commission on Violence Against Women, one of concerning issues related to women is rape. By percentage, the number of rape reaches 699 while sexual harassment reaches 704 and sexual assault tops at 991. Based on The National Commission of Violence Against Women, rape is an assault targeting sexual body parts and/or someone's sexuality by using a male sexual organ (penis) into another women sexual organ such as vagina, mouth, or anus, or by using other body parts which are not sexual organs. It is done with violence, with intimidation or threats that lead the victim to feel afraid of violence, by force, under incarceration, psychological intimidation, by abuse of power, or by taking advantages of a coercive environmental situation, or done to someone who is not competent enough to give her true consent. I chose Javanese culture as background of the story. The reason of choosing the rape survivor as a Javanese Indonesia, especially East Java, is because this province is one of the top five with the highest number in rape cases and also many of the citizen in this province can be considered as more conservative rather than other places in Indonesia (Syafi' i, 2018).

In Indonesia, rape is a serious issue that needs to be addressed because many of rape victims do not report their cases due to their distrust towards legal institution (Lestari, 2017). Rape cases are often coloured by victim blaming, putting the pressure on the victim (Lestari, 2017). The statistic shows that only $1 \%$ from 25,214 respondents report their cases and legally resolved (Lestari, 2017). In November 2018, victim blaming in a latest sex abuse case that happened in Gadjah Mada University (UGM) was a tense issue (Mariani \& Wahyuni, 2018). It shows that it is unfinished issue in society.

The issue that I really want to address in here is the tragic condition of rape survivors that face not only their psychological struggles due to trauma but also victim blaming culture. Victim 
blaming itself is a term to show a condition where the victim is blamed because the incident that happened to the victim (Goodtheraphy, 2016). The forms victim blaming itself can be embodied as verbal abuse, disbelieving victim's story, stigmatized, humiliations and disowned by family or friends which worsen their already fragile state. In Indonesia victim blaming often appears in many incident especially women in rape cases. The victims are often blamed in rape experience because of the action that they make and the clothes that they wear. It becomes an issue that needs to be address especially in a rape case because it becomes another burden.

Along with victim blaming, the rape survivor has to deal with mental disorder or mental illness which carried out after the tragic event. Post Traumatic Stress Disorder (PTSD) is a mental illness which often arise in people experiencing traumatic incidents; signified by recurring nightmares, anxieties, and flashbacks relating to their traumatic memory (Maslim, 2013). In context, PTSD can appear as a mental illness from a traumatic event which, in this case, is the rape itself. PTSD symptoms are generally grouped into four types: intrusive memories, avoidance, negative changes in thinking and mood, and changes in physical and emotional reactions (Maslim, 2013). Symptoms can vary over time or vary from person to person. The symptoms may start within one month after the traumatic event and use significant problem in social or work situation and in a relationship. However, instead of finding sanctuary to soothe their PTSD, victims are instead silenced by wrong treatment from their society to heal. As a metaphor, a baby who is sick with fever will die without treatment. An untreated rape survivor often face long-term mental sickness that may decapitate their capability of living normally or even choosing suicide.

For this creative thesis, I choose a screenplay as the media to address the issue that I want to present. First of all, screenplay is a suitable medium to address the issue because it will not stop with the people who are reading it. It also has a huge possibility to be produced by some production houses and group productions. Thus, the issue that I want to address can be shared. Furthermore, film is a promising media in creative economy sector who significantly contributes Indonesia gross domestic product (GDP) into top two in 2018 (Saputri, 2018). Mr. Joko Widodo, Indonesian President, stated that Indonesia's film industry has a significant growth in terms of consumption (Sulistiyono, 2018). It is proven by the increasing number of cinema theatre and the tickets sales in Indonesia in 2018 which are three times higher in the past two years (Saputri, 2018). Due to its requirement in film making, a screenplay is a major need to create a movie production. My screenplay is colored by my willingness to give rape survivor a better chance to heal towards the survivors surrounding.

Marlina, the Murderer in Four Acts (Adi \& Surya, 2017) and Irreversible (Noé, Chioua, \& Cassel, 2002) are two films that inspire me to create this kind of creative works. The main attention between Marlina and my story is dealing with women who are surprised by society even though it deals with different problem. Marlina itself tells about a widow who is raped and her cattle are stolen. Later in the story, she takes a revenge for those who do such things to her. On the other hand, Irreversible share the same issue relating to rape and sexual abuse. The main idea between both stories and my story can be considered as familiar. Both of the stories show women as victims. It shows an abuse toward women. The lost of power and rights of women and human being drives them into certain condition which in my story is embodied as PTSD.

By creating this creative work, I want the audiences to have a glimpse of the tragic experience. Hence, I chose drama which I thought could represent the crisis that I would like to convey. According to Matthew Cooper (2012), drama film is a genre that intended to be more serious and heightened emotion through the character's journey. Drama is created to move the audience emotionally. Obviously, since the main idea of the story is related with a great crisis that happen to the rape survivor, using drama is the most suitable one. I specifically use this genre to 
highlight the misery and grave condition of the rape survivor herself in order to heightened the audience's emotion.

The creative work that I am going to make is about a graduate student and singer at the same time who grows up in a Javanese Indonesian conservative family. She drowned in a metropolitan nightlife which later drives her to be a rape victim. After the tragic event, Maharani is forced by her family to marry a guy who raped her and pretend to live happily. Not only dealing with rape trauma syndrome, Maharani has to struggle with the social pressure that vividly intimidates her. To escape from her problem which suppresses her, she tries to speak up and show to her family about the things that happened before the incident and expresses her feeling through a song that she creates. By the end of the story, she chooses to kill herself and left the song and a voice recording that she produced after knowing that she cannot deal with her life anymore.

Personally, I care about this issue because it happened to people around me. Hence, by creating this project I could pass along the message; victim blaming is an act of killing, and it should be stopped.

\section{OUTLINE OF CREATIVE WORK}

\subsubsection{Theme}

The issue of my story is rape and the theme that I want to explore in my story is victim blaming is worsening post-rape survivor's PTSD. In my story, the rape experience which creates the trauma is the one which drives the survivor to deal with Post Traumatic Stress Disorder. The theme is clearly shown in the story when Maharani is getting suppressed from her family and people around her even though she tries to heal from PTSD. She is a graduate student and singer at the same time who grows up in a Javanese Indonesian conservative family. She drowned in a metropolitan nightlife which later drives her to be a rape victim. After the tragic event,

Maharani is forced by her family to marry a guy who raped her and pretend to live happily. Not only dealing with rape trauma syndrome, Maharani has to struggle with the social pressure that vividly intimidates her. To escape from her problem which suppresses her, she tries to speak up and show to her family about the things that happened before the incident and expresses her feeling through a song that she creates. By the end of the story, Maharani tries to overcome her stress by consuming the drugs given to her which later make her over dose and die.

\subsubsection{Pitch}

1. Maharani is a post-rape survivor who wants to heal from her trauma because of rape experience.

2. Maharani's PTSD is getting worse after people around her (husband, family and friends) suppress her through victim blaming.

3. Maharani is often tempted to kill her family and husband and write a song as a form of escapism.

\subsubsection{Synopsis}

Maharani is a graduate student of a private university and a singer at the same time who is born and raised in Javanese conservative family. She is an innocent girl and very talented who had never gone out late before. The story begins when Maharani has to pretend to live happily after marry her best friend and also her guitarist who is Marvin. Trying to live normally and heal from her PTSD, her family is worsening her fragile psychological state by directly and in directly blaming her about Maharani's past and keeping her marriage status with Marvin. 
Along with reviling the truth that Maharani is raped by Marvin, she creates a song as an escapism from her reality. Receiving worse treatment from her family especially her parents, Maharani tries to overcome her stress by consuming the drugs given to her which later make her over dose and die.

\subsubsection{Step Outline}

1. It is Maharani's wedding day. The ceremony is conducted in a mosque. She seems happy.

2. (Flashback) Maharani and her family are on the way to her graduation ceremony. She talks about her future with her father.

3. Back to Maharani's wedding day. She still seems happy. Her friends are coming to her wedding ceremony.

4. (Flashback) It is Maharani and her friends. They take a graduation picture.

5. Back to Maharani's wedding day. Maharani and Marvin are having pictures with their friends.

6. Maharani wakes up in her room. Marvin is sleeping beside her. She looks anxious with herself and Marvin. She goes out.

7. Maharani is in her bathroom. She remembers about the other night when her friends invite her to a party.

8. (Flashback) Maharani is in her bathroom. She has a call from her friend. Her friend asks her to have a night party.

9. Back to Maharani is in her bathroom. She is crying.

10. Maharani is in the car on the way to a psychiatrist. She motivates herself by listening to a podcast.

11. Maharani is in a psychiatrist room. Maharani confesses that she wants a divorce to the psychiatrist. Psychiatrist asks her to consume the drugs given.

12. Maharani is having a call with Ayu who is her friend. Ayu offers her a music production. Ayu also talks about their past regarding music band. Maharani feels pressured by Ayu's reaction. While Maharani ends the call, Marvin enters the room and asks her about Maharani's pregnancy and doctor check up.

13. (Flashback) Maharani is having a video group call. They talk about being adult. Maharani confess that she likes kids. Other than that, they also talk about the night party.

14. Back to Maharani's room when Maharani and Marvin are having conversation. Maharani emphasizes to Marvin that the baby inside her stomach is not her baby. Maharani does not like its presence. In this two separates scene, 12 and 14, Maharani feels pressured by both Ayu and Marvin's questions and expression. Maharani takes the drug.

15. Maharani is in the living room. There are some religious and cultural symbol hanging on the wall. There are also Maharani, Marvin, Susanto, Farida, and Ayu. Susanto asks Maharani regarding her pregnancy and doctor check up. Susanto is mad at Maharani because she does not go to the doctor. He brings up Maharani's past to the conversation. Maharani is discredited by Susanto's reaction. She is blamed by her own choice.

16. Maharani is in her working room. She is depressed. She slits her writs. She remembers the day when her friends arrive at her house and pick her up to the night party.

17. (Flashback) Maharani tries to refuse her friends who already in her house.

18. Back to Maharani is in her working room. She cries. She finds a paper which contains music lyric. She rewrites it again.

19. It is dinner time. Maharani confesses to her parents that she wants a divorce. Susanto disagrees with Maharani because she already has a baby. He forbids her to have a divorce.

20. (Flashback) Maharani and her friends are in the living room. She lies to her mother about the night party.

21. (Imagination) Back to dinner time. Maharani is depressed by her father. She takes a knife and stabs it to her stomach.

22. Back to dinner time. Maharani is depressed by her father. She choses to leave the room. 
23. Maharani is in her working room. She is crying.

24. (Flashback) Maharani is on the way to the night club.

25. Back to Maharani is in the working room. She continues writing the music lyric.

26. (Flashback) Maharani is in the night club. She meets more people.

27. Back to Maharani is in her working room. She keeps writing.

28. (Flashback) Maharani is in the night club. She is so anxious with the situation. A friend tries to make her adapt with the situation.

29. Back to Maharani is in her working room. She throws the paper and hits the piano over and over.

30. (Flashback) Maharani is carried with the night club situation.

31. (Flashback) Marvin takes Maharani and her friends out from the night club.

32. Back to Maharani is in her working room. She makes another cut. She looks at the stomach and finds abortion procedure in her laptop.

33. Maharani is in the Recording House. She waits the producer in the waiting room.

34. Maharani is in Margaret's office. She purposes to produce the song. She tells the producer about the song. Maharani illustrates the story as another woman.

35. (Flashback) Maharani asks Marvin to drive her home. Maharani looks sensual in a way.

36. (Flashback) Maharani and Marvin are in the car heading Maharani's home.

37. (Flashback) A moment later. Maharani is raped by Marvin in the car.

38. (Flashback) A moment later. Marvin apologises Maharani. Maharani is in her trauma.

39. (Flashback) A moment later. Maharani enters the house and meets Farida. Farida is suspicious to her.

40. (Flashback) A moment later. Maharani is crying in her room.

41. Back to Maharani is in Margaret's office. Maharani continues telling Margaret about the story which is worsen.

42. (Flashback) Maharani finds out that she is pregnant.

43. (Flashback) Maharani joins her family who are enjoying a family time. Marvin is coming to the house. Both Maharani and Marvin are speechless. Maharani cries. She confesses to her parents that she is pregnant.

44. (Flashback) Maharani is in her room. She is crying. Voices of her father's anger is filling her head. Susanto keeps blaming her for the things that happen to her.

45. (Flashback) Back to Maharani is in her wedding day. The voice of her father's anger is still in her head.

46. (Flashback) Back to Maharani is in her room while she is sleeping with Marvin. She is depressed with all the situations happen.

47. Back to Maharani is in Margaret's office. Margaret suggests the woman in the story to have a divorce.

48. Maharani is in the hospital with her mother to have a doctor check up. Her mother really wishes that the baby is a he.

49. It is family dinner time. Susanto keeps lecturing Maharani which suppresses her.

50. Maharani is in the taxi. She is heading to an abortion clinic.

51. Maharani is in the abortion clinic. She prepares herself to have the abortion.

52. Maharani is in the abortion room. She does the abortion.

53. A moment later. Maharani is in the abortion clinic. She calls Marvin to pick her up.

54. Maharani and Marvin are on the way to their house. Maharani tells Marvin that she had the abortion.

55. Maharani says to her mother that she wants to conduct family meeting.

56. Late night in the dining room. Maharani tells her father that she already aborted the baby and asks for a divorce. Susanto and Farida are angry with her. Susanto forbids her to have a divorce. Marvin agrees with Susanto's request to keep their marriage. Marvin asks Maharani to build their family again and makes another baby. Both of the requests remain Maharani to her trauma. Maharani begins imagining things. 
57. (Imagination) Maharni enters her bedroom where she finds out that Marvin is sleeping. She brings a knife with her. She stabs Marvin with the knife.

58. (Imagination) Maharani enters her parent's bedroom. She stabs her father and mother alternately.

59. Back to Maharani is sitting in the dinning room.

60. She enters her working room. She records the music that she plays. She drinks the drug.

61. Maharani is in her bath room. She drinks all her drugs and become over dose. She leave the phone which consist of looping recorder next to her.

62. A moment later. Marvin forcefully enters the bath room and finds out Maharani is dead. Susanto and Farida follows. Farida takes Maharani's phone and listen to the recording. Everyone in the room is listening to the recording.

63. (Montage) Marvin looks at Maharani always cries in the room.

64. (Montage) Marvin rapes Maharani inside the car.

65. (Montage) Susanto yells at Maharani. He slaps her face.

66. (Montage) Maharani and Marvin's wedding.

67. Back to Maharani lies on the tube. Her mother is crying. Susanto tries to lift the corp out of the tube.

68. (Flashback) Maharani ends her recording.

\subsubsection{Characters and Supporting Characters}

1. Maharani Ayu Dewi, 21 year-old

2. Marvin Octarico, 21 year-old

3. Susanto Adibuwono, 55 year-old

4. Farida Hasibuana, 49 year-old

5. Ayu, 21 year-old

6. Rama, 21 year-old

7. Ken, 20 year-old

8. Margaret, 35 year-old

9. Headman, 40 year-old

10. Aisyah, 17 year-old

11. Psychiatrist, 45 year-old

12. Doctor \#1, 50 year-old

13. Doctor \#2, 40 year-old

14. Nurse, 25 year-old

15. Man On The Podcast

16. Woman On The Podcast

17. Man On The Television

18. Maid, 60 year-old

19. Photographer, 35 year old

\subsubsection{Conflict}

The major conflict is between Maharani and people around her. Thus, the conflict is between men vs men. Maharani is raped by her own best friend named Marvin after they go back from a night party. As a result, she gets pregnant and PTSD at the same time. Knowing that she is pregnant, she needs to deal with her conservative Javanese family who considers Maharani's act as a sinner and immoral. Maharani who suffers from PTSD tries to heal her disorder by consulting with psychiatrist so she decides to divorce with Marvin. However, people around her especially her parents do not support her. By the end of the story, Maharani is dead because of overdose. 


\subsubsection{Setting}

1. Surabaya, Indonesia.

2. Car

3. Mosque

4. Campus Hall

5. Maharani's Bedroom

6. Maharani's Bathroom

7. Psychiatrist room.

8. Living room.

9. Maharani's Working Room.

10. Dinning Room

11. Night Club

12. Label House

13. Margaret's Office - Recording House

14. Susanto and Farida's bedroom.

15. Hospital

16. Taxi

17. Waiting room - Abortion Clinic

18. Abortion room - Abortion Clinic

\section{CONCLUSION}

In this part, I would like to restate the purpose of the creative work I had established and that I manage to show them in my creative work.

First of all, the purpose of my creative work is to show how Maharani's PTSD worsened due to verbal abuse, not believed, stigmatised, humiliated, and disowned by the people around her. In the story, Maharani has to dealt with PTSD because of the incident which worsens after she is asked to marry Marvin (the stigma that her parents give to Maharani). Moreover, Susanto blames her regarding the clothing that Maharani wears at the time Maharani went out from home and the place that Maharani visited. Susanto believes that those are the reasons why Maharani was raped. The reaction that Susanto and Farida give towards Maharani can be considered as verbal abuse and stigmatization. Maharani's parents also humiliated and disowned Maharani by considering Maharani as sinful and no longer pure. In short, those reactions that people around Maharani give are worsening her psychological state. It is proved by Maharani's reaction such as crying and enacting self-harm.

Last but not least, due to Maharani's fragile mental state, she experiences gruelling self defense mechanism through PTSD and self-harming before making a breakthrough by speaking up and showing her side of the story behind the tragic event and expresses her feeling through a song that she is going to produce. Maharani confesses to her parents that she cannot handle her relationship because she cannot live with her rapist. Thus, Maharani speaks up to her parents and Marvin that she wants a divorce. However, along with the rejection that her parents and Marvin give, Maharani expresses and escapes from the reality through the music that she writes and she produces.4.2. Lesson Learned 


\section{REFERENCE}

Adi. R. (Producer) \& Surya, M. (Director). (2017). Marlina the Murderer in Four Acts. [Film]. Indonesia: Cine Surya.

Brahim Chioua (Producer) \& Gaspar Noe (Director). (2002). Irreversible. [Film]. France: Les Cinemas de la Zone.

Cooper, M. (2012). Codes and Convention of Drama. Retrieved from https:// www.slideshare.net/coopermatt62/codes-and-conventions-of-drama

Lestari, S. (2017). 100 Women: Pengalaman Korban Perkosaan Saat Melapor ke Polisi. Retrieved from https://www.bbc.com/indonesia/ indonesia-41691743

Mariani E \& Wahyuni S. (2018). 'Victim Blaming' in Latest UGM Sex Abuse Case Angers Thousands. Retrieved from https://www.thejakartapost.com/news/ 2018/11/07/victimblaming-in-latest-ugm-sexual-assault-prompts-thou- sands-to-call-for-action.html

Maslim. (2013). Post-Traumatic Stress Disorder (PTSD). Retrieved from http:// hmku.fkunud.com/ptsd/

Saputri, K. (2018). Film Memiliki Pertumbuhan Sumbangan PDB Terbesat Ked-ua. Retrieved from http://www.bekraf.go.id/berita/page/8/film-memiliki- pertumbuhan-sumbanganpdb-terbesar-kedua

Sulistiyono, S.T. (2018). Jokowi Apresiasi Pertumbuhan Film National. Retrieved from http://www.tribunnews.com/nasional/2018/03/29/jokowi-apresiasi- pertumbuhan-filmnasional

Syafi'i, M. (2018). Inilah Provinsi Paling Rawan Pelecehan Seksual. Retrieved from https://faktualnews.co/2018/01/25/inilah-provinsi-paling-rawan- pele- cehanseksual/59935/

Good Therapy (2016). Retrieved from https://aus.libguides.com/apa/apa-no-au- thor-date 